\title{
Hunting Farming as Innovative Direction of Integrated Development of Rural Areas
}

\author{
Laricheva $\mathrm{K}$.* \\ Yaroslav-the-Wise Novgorod State University \\ Veliky Novgorod, Russia \\ e-mail: Kristina_plus@mail.ru
}

Lapteva $\mathrm{N}$.

Yaroslav-the-Wise Novgorod State University

Veliky Novgorod, Russia

\author{
Petrova A. \\ Yaroslav-the-Wise Novgorod State University \\ Veliky Novgorod, Russia
}

Osipova M.

Yaroslav-the-Wise Novgorod State University

Veliky Novgorod, Russia

\begin{abstract}
The article substantiates the need for integrated development of rural territories. This article substantiates the need for integrated development of rural territories. The possibility of developing rural areas through special methods of farming based on the joint use of agricultural and nonagricultural resources (biological resources of the animal world, forestry land and agricultural land) is shown. The organization of agrotouristic hunting complexes is proposed, and they are considered a viable alternative to agricultural enterprises. The integrated activities of agrotouristic hunting farms are not only aimed at mass hunting sport, but will also ensure the viability of nearby rural settlements, focusing on the development of rural, ecological, gastronomic, cultural, educational, event and sports tourism. The functionality and significance of the proposed business idea for the "healthy" development of rural areas, with particular attention to priority social areas, are noted. In order to assess the appropriateness of a business idea, a pilot project of an agrotouristic hunting complex has been developed as part of the study.
\end{abstract}

Keywords - rural development; agrotouristic hunting complexes.

\section{INTRODUCTION}

The integrated development of rural territories in modern Russia occupies an important place. The standard of living of the rural population, its well-being, physical and social health is a fundamental criterion for a dynamic development of rural areas. Attention to this problem is associated with a decrease in the rural population. In 2009, the population of rural Russia amounted to $31 \%$ of the total population of the country, in $2014-26 \%$, in 2019 this figure dropped to $23 \%$ [1]. In addition to the outflow of the population from rural settlements, there is also a steady decrease in the number of agricultural workers. The experience of other countries in economic development shows that employment in agricultural production will continue to decline. Only new alternative methods of farming will expand the range of motivations of farmers and maintain the viability of rural settlements. In this regard, I would like to draw attention to the experience of the countries of Southeast Asia, the USA, Brazil, Romania, Italy and other European states. These countries deal with the most important questions: their ability to rationally distribute agricultural resources, to effectively solve the problems of food security and to increase the competitiveness of agricultural products through the joint presence of various activities [2-6].

The problems of the quality of life of the rural population require a certain policy developed by the governing bodies. In this regard, the government pays great attention to state agrarian policy. According to the state program approved in Russia in 2019, in order to strengthen support in the field of integrated rural development, subsidies are introduced for integrated rural development projects. Such projects include activities to develop traditional crafts.

\section{RESULTS AND DISCUSSION}

Rural territories of the Russian Federation have great natural potential. However, for many decades, the development of the agricultural environment has been focused only on agricultural activities.

We believe that for the modern agricultural environment, the simultaneous interaction of various practices, focused not only on the agricultural sector, is necessary. In this direction, we draw attention to subsidiary crafts, forestry, as well as the tourism industry and social infrastructure $[7,8]$.

A special way of farming is proposed on the basis of a new model, which implies the effective joint use of agricultural and non-agricultural resources. An exceptionally new concept is proposed, it is based on the integrated use of biological resources (fauna of the animal world, forest land, agricultural land). So, it is proposed that traditional rural crafts, which include hunting, are transformed and reoriented to modern conditions for the diversification of rural areas. The reorganization of crafts will consist in changing the classical mechanisms of crafts. Therefore it is proposed to update the mechanisms of conducting traditional rural crafts through the organization of innovative agrotouristic hunting complexes. Integrated activities in this kind of agrotouristic hunting farms will be aimed at improving the environment and the rural settlements. Such a transformation will give one a chance to revive traditional types of environmental management, the production of environmentally friendly products, to activate hunting and crafts. A strong emphasis in the framework of such an update is on the development of several types of 
tourism: rural, environmental, gastronomic, cultural, educational, event and sports tourism [7, 9].

Note that more than $60 \%$ of the forest fund lands are practically not used. Rural forests are not involved in the economic turnover. The organization of agrotouristic hunting farming in an abandoned territory, the revival of defunct villages, in addition to the economic effect, can also give a very large social one [7]. Unused land resources can get a very real chance to become a promising platform for organizing profitable activities. Coordinated proportional land use is an important task for both agriculture and rural development. The proposed areas will allow not only "reanimating" arable lands, abandoned hayfields and pastures, but also using the wasteland, burning land, felling areas abandoned by shrubs and reviving abandoned villages.

We draw attention to the fact that it is impossible to separate biological resources from agricultural resources, since the expansion of agricultural land can only happen at the expense of natural objects. So forest land can be considered a biological resource in its natural form or as a resource of the agricultural sector - potential or existing (for example, natural fodder land). So it is supposed to use land not only for production, but also as an ecological niche for wild ungulates.

To test the viability of the unique proposed solution, a pilot project of an agrotouristic hunting complex was developed as part of the study. The idea of the project was the possibility of organizing a demonstrative (experimental) agrotouristic hunting complex for keeping, breeding and raising wild ungulates. The idea of the project is to popularize agritourism and attract tourists with a non-trivial approach to hunting, as well as with an unusual range of services. A kind of farming will be in many ways similar to the technologies used in the livestock industry. The innovative nature of the project is expressed in organizational, technological, product and social innovations. More specifically, what happens is: updating the management system, improving the mechanisms of crafts, modeling new products and services, the process of reforming the spheres of human life.

The perspectivity and significance of the proposals lies in the multifunctionality (economic, environmental, social, recreational, research, educational functions) of the agrotouristic hunting park (Fig. 1.) and the ability to coordinate their activities with other sectors of biological environmental management, which include the following: rural (to a large extent), forestry, hunting facilities.

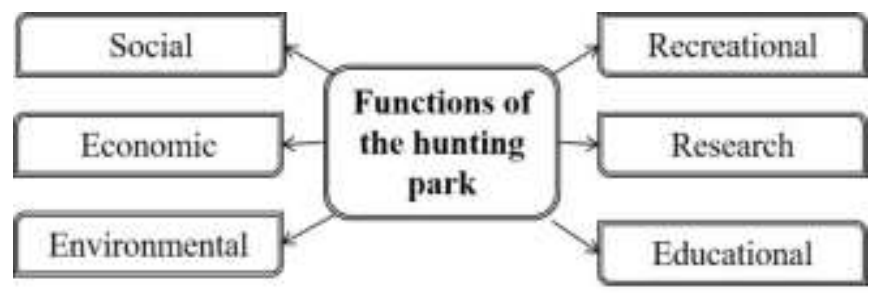

Fig. 1. Functions of an agrotouristic hunting park
The social function is manifested in the fact that the activity of such an extraordinary hunting farm is aimed not only at mass hunting sports, but will also ensure the viability of villages and villages located nearby. The sustainable impact of agrotouristic hunting complexes on the environment and the "recovery" of rural areas cannot be separated from the economic, social and cultural life of the population. Such an impact has a multiplicative effect on all spheres with which it interacts $[7,10]$.

The priority social areas of the proposed development are presented in the Figure 2.

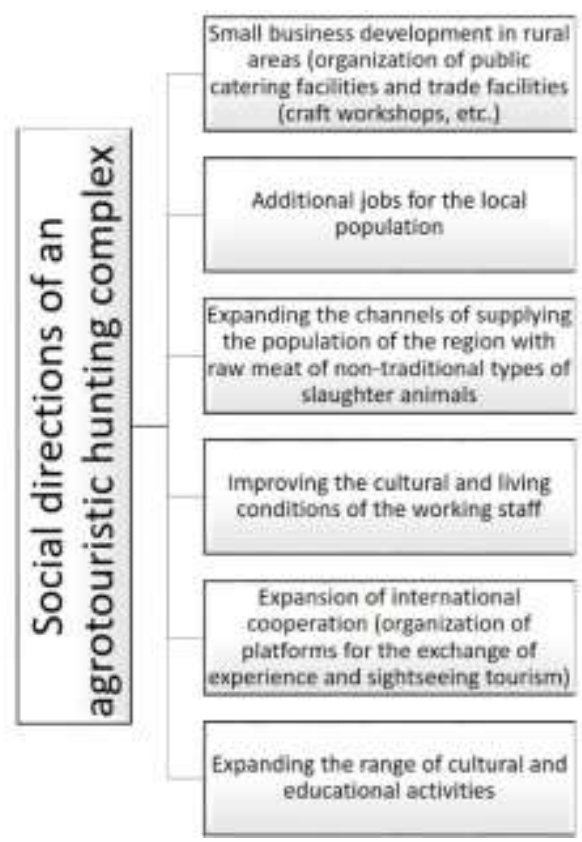

Fig. 2. Social directions of an agrotouristic hunting complex

A feature of agrotouristic hunting complexes is that their visitors will not only be overs of sports hunting, but also gastronomical tourists. It is assumed that the hunting complex will attract a tourist stream of environmentally friendly and safe products. Re-profiling of the forest gifts to the resource base, development of the infrastructure appropriate for the restaurant will ensure the self-sufficiency and competitive advantages of the complex.

Tourism provides an opportunity to get acquainted not only with the culture of the region, its traditions, sights, but also with local products, which are now singled out as a separate type of tourism - gastronomic.

The development of the tourism industry in the 21st century is inextricably linked with the development of gastronomic tourism. Today, gastronomic tourism has become one of the fastest growing innovative areas of tourism. According to a survey held by the World Tourism Organization (UNWTO), in which 156 countries participated, $88.2 \%$ of respondents consider gastronomy a strategic element in determining the brand of a region [11-13]. 
According to the studies of world experts, about $40 \%$ of the money tourists spend on the purchase of products that the area is famous for and the purchase of gastronomic souvenirs. It is the taste experience that is often associated with the image of a city or a country.

Currently, there is a special interest of consumers in wild meat feedstock. A spoiled consumer seeks new tastes, forcing manufacturers to respond to the most exclusive requirements.
Wild meat attracts the meat industry with its exoticism and safety. As part of the study, a series of experiments were conducted to compare the chemical composition of wild boar meat (brawn) with meat of a pig grown under industrial conditions (pork). The studies were carried out on the basis of the training laboratory of the "Technology of production and processing of agricultural products" department of the Yaroslav-the-Wise Novgorod State University. The results are presented in the diagrams (Fig. 3-5).

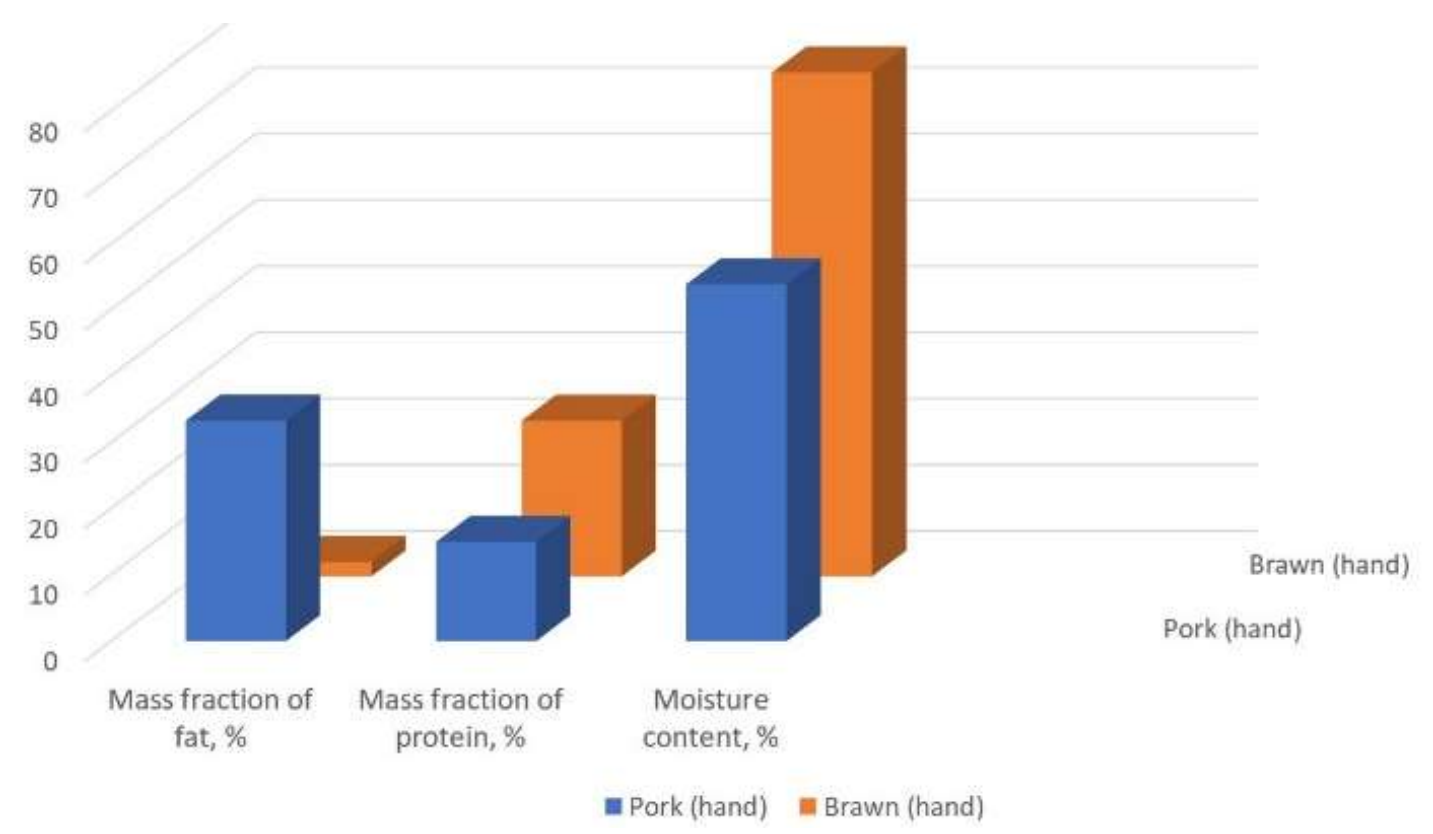

Fig. 3. The chemical composition of a hand of pork and of brawn

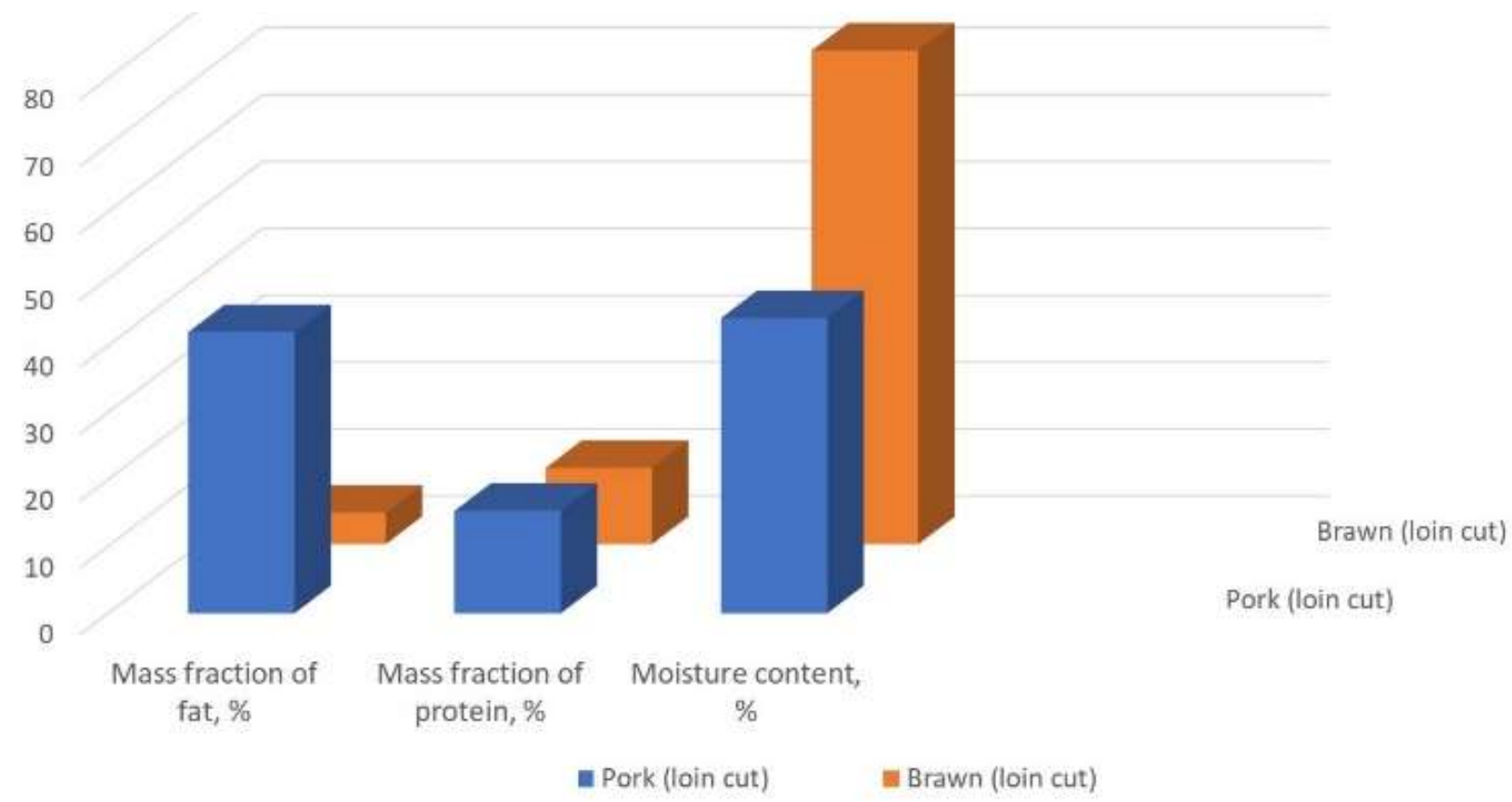

Fig. 4. The chemical composition of a loin cut of pork and of brawn 


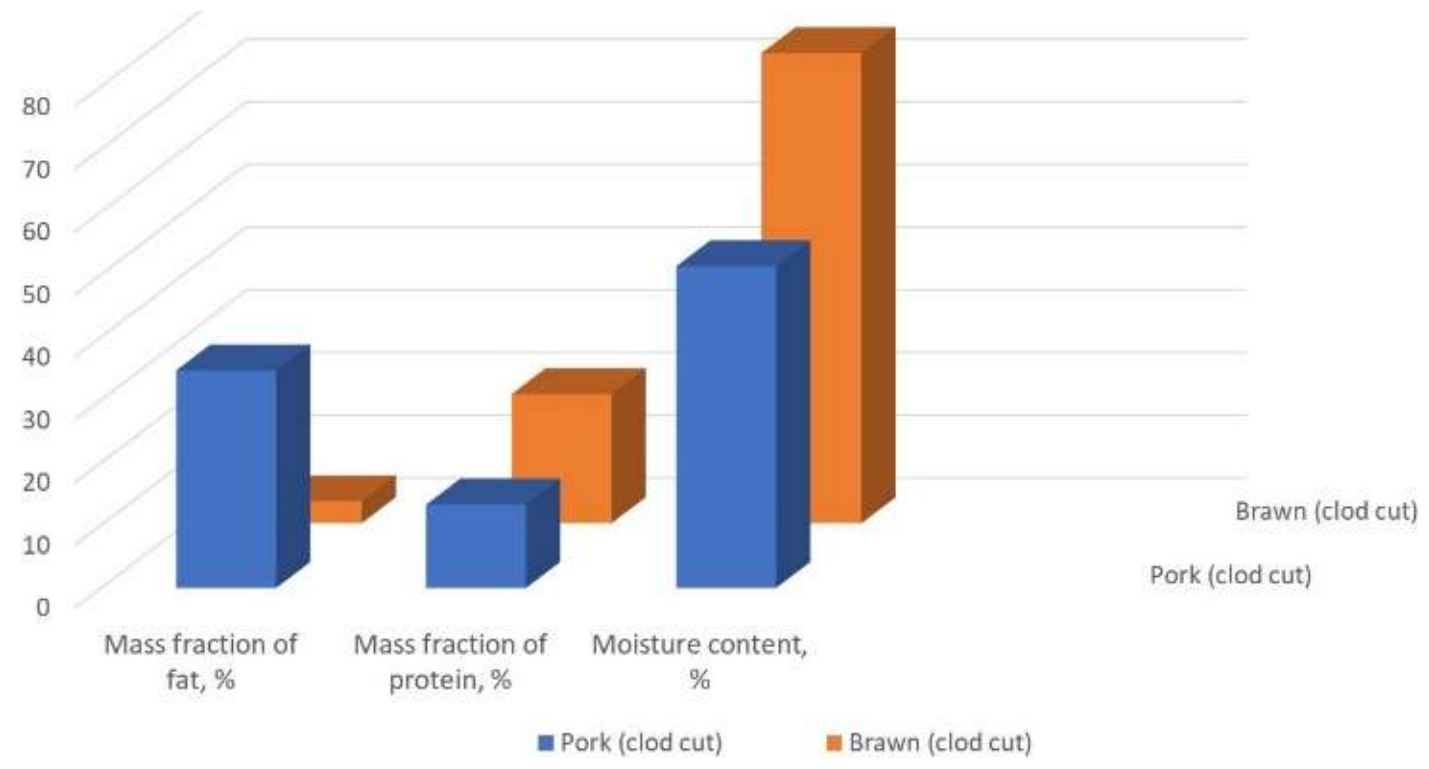

Fig. 5. The chemical composition of clod cut of pork and of brawn

The diagrams give a visual representation of the chemical composition of the studied objects. Due to the large amount of protein and low fat content, wild boar meat (brawn) can be attributed to a low-calorie delicacy. The obtained results substantiate the significance of the proposals for the development of gastronomic tourism.

The economic function of the hunting complex is to profit from the sale of marketable products and services. A detailed list of commercial products and services is presented in the monograph of K. Laricheva, "Organization of cultural hunting economy" [14].

The environmental function is aimed at preserving and expanding the animal gene pool; protection from predators, poachers and diseases.

The recreational function is based on the provision of services in the field of several types of tourism.

The research function is to conduct research in conjunction with relevant educational institutions.

The educational function is that the agrotouristic hunting complex can serve as a platform for conducting field training on relevant topics in the format of "Lecture-visualization".

The development of a model project for an agrotouristic hunting complex was carried out in several stages. The development of a business plan structure was based on generally recognized principles and internal logic. The structure itself is universal. At the same time, the developed project is unique and has differences and specificities that more closely meet the project objectives. The structure of the business plan of an agrotouristic hunting complex project consists of the following main sections: justification of the business idea of the project; characteristics of the conditions for the implementation of the project; marketing, investment, production and financial plans (Fig. 6). At the first stage, the analysis was made of the situation in the industry, monitoring the dynamics of quantitative indicators of wild ungulates in the Novgorod region and appraisal of hunting grounds [7, 14]

To select a site for the construction of the facility, we took into account the overall weighted average land valuation. A site for an agrotouristic hunting complex was selected based on the study of numerous works by foreign and Russian researchers, owners of such objects (Fig. 7) [7, 14].

The location for the hunting complex was selected taking into account the value of the land for animal habitation and in accordance with the consumer preferences of a modern potential client. The advantages of the selected site include: favorable economic and geographical position; the presence of unused land and labor shortages; relatively close location of the road and energy resources.

The square area of the agrotouristic hunting complex will be approximately 800 hectares. The area was selected taking into account the fact that both breeding and rising of the beast are provided. The proposed site will be fenced to isolate the hunting complex from neighboring lands, it will consist of cultivated areas, natural pasture ( 80 hectares), forest zone (700 hectares) provided with water resources. Fields are surrounded by a dense forest. For the convenience of biotechnological events, it is planned to place the feed fields near the road evenly along the perimeter of the complex in small sections of $0.15-0.4$ hectares. 


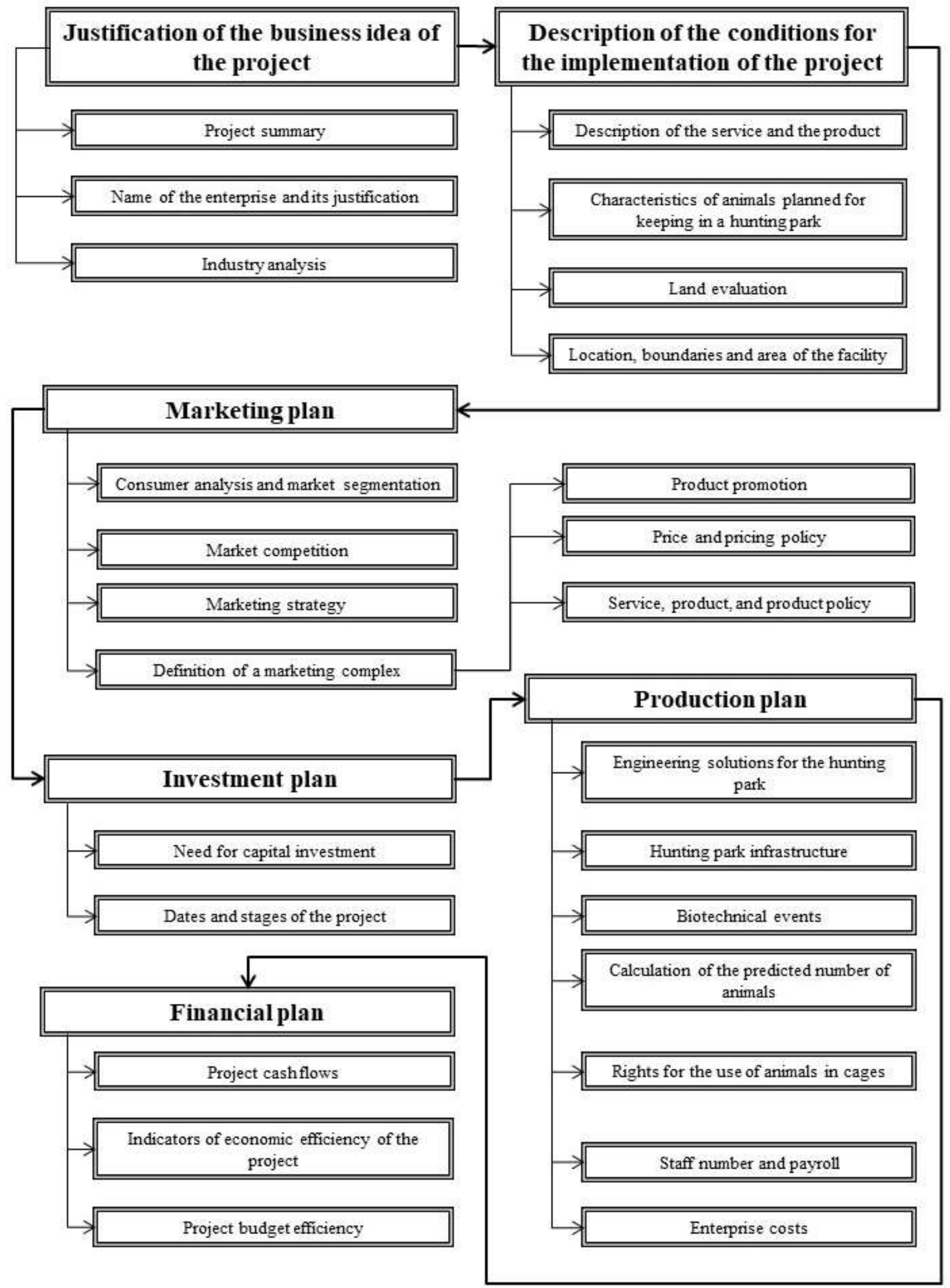

Fig. 6. The structure of the business plan of the agrotouristic hunting complex project 


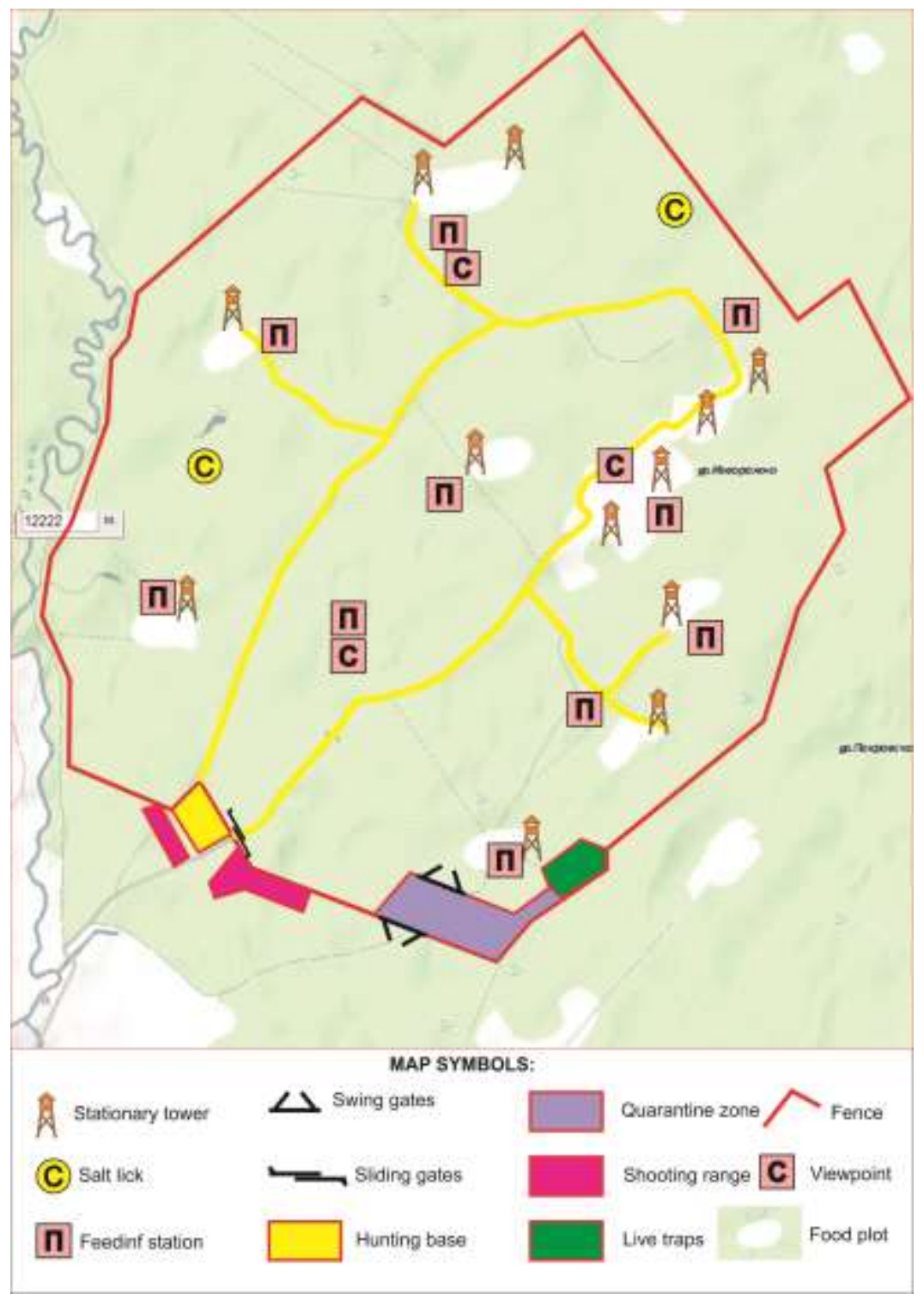

Fig. 7. The plan-scheme of the territory of agrotouristic hunting complex

The next stage of the work was the analysis of consumers, market segmentation and assessment of the competitiveness of services and products of the agrotouristic hunting complex. Market segmentation allowed distinguishing four main groups of customers (Table 1).

TABLE I. MARKET SEGMENTATION FOR AGROTOURISTIC HUNTING COMPLEX

\begin{tabular}{|l|l|}
\hline Segment & \multicolumn{1}{|c|}{ Consumer characteristics } \\
\hline First & Regular customers - hunters \\
\hline Second & $\begin{array}{l}\text { Regular consumers of meat and delicatessen products of this } \\
\text { complex (processing industry, restaurateurs, consumers with } \\
\text { discerning taste) }\end{array}$ \\
\hline Third & $\begin{array}{l}\text { Consumers who pursue the goal of educational or eco-tourism. } \\
\text { These are those visitors who want to combine leisure and } \\
\text { learning. }\end{array}$ \\
\hline Fourth & One-time customers \\
\hline
\end{tabular}

The fourth segment deserves special attention from the complex manager. The main task is to turn one-time customers into regular ones. For this, it is necessary to constantly monitor consumer preferences and to flexibly adapt to them.

Next, the resource potential of the complex was predicted.

As part of the investment plan, the calculation of the need for capital investments, the terms of implementation and the stages of the business project (preparation of a package of documents; construction of an agrotouristic hunting complex; purchase of equipment, agricultural equipment, transport, tools; hunting, sports and tourist equipment; creation of a system of fodder fields; organizational measures to launch animals into the park) [7, 14-17].

The production plan included sections on engineering and technical solutions, infrastructure development, 
biotechnological measures, and determination of enterprise costs.

The financial plan involved calculation of economic efficiency from the implementation of the project. The calculation showed that it would take about five years to fully recover the investment in the project. Considering the genetic potential of wildlife productivity, production cycle features and environmental and climatic factors, the resulting payback period is acceptable. Detailed calculations are presented in the monograph of K. Laricheva "Organization of cultural hunting economy" [14].

\section{CONCLUSION}

Thus, the implementation of such business ideas can be a driving force in improving the well-being of rural areas. The involvement of local natural resources in the joint activities of hunting, forestry, agriculture, in cooperation with the food, light and other sectors of the agro-industrial complex, will solve the problem of mass poverty of rural residents and become the key to "healthy" rural development. It is predicted that the organization of agrotouristic hunting complexes will be able to have a modernizing effect on the living standards of the rural population.

\section{References}

[1] L.V. Skulskaya, T.K. Shirokova, "Modern conditions for the development of rural territories of Russia", Sci. works: Instit. of Econ. Forecast. RAS, vol. 13, pp. 240-260, 2015.

[2] E.R. Kokova, "Priorities and mechanisms for the development of rural territories", Bull. of the Expert Council, vol. 1-2, no. 12-13, pp. 36-40, 2018.

[3] B. Arru, R. Furesi, F.A. Madau, P. Pulina, "Recreational Services Provision and Farm Diversification: A Technical Efficiency Analysis on Italian Agritourism", Agricult., vol. 9, no. 2, pp. 42, 2019.

[4] Amanor-Boadu "Diversification decisions in agriculture: the case of agritourism in Kansas", Int. Food and Agribusin. Manag. Rev., vol. 16, no. 2, pp. 57-74, 2013.

[5] M.-L. Tseng, Ch.-H. Chang, K.-Ju. Wu, Ch.-W.R. Lin, B. Kalnaovkul, R.R. Tan, "Sustainable Agritourism in Thailand: Modeling Business
Performance and Environmental Sustainability under Uncertainty", Sustainability, vol. 11, no. 15, pp. 4087, 2019.

[6] E. Chiodo, A. Fantini, L. Dickes, T. Arogundade, R.D. Lamie, L. Assing, C. Stewart R. Salvatore, "Agritourism in Mountainous Regions - Insights from an International Perspective", Sustainability, vol. 11, no. 13, pp. 3715, 2019.

[7] K.N. Laricheva, Development of traditional rural crafts based on the innovative use of biological resources (on the example of the Novgorod region) (Cand. Dissertation). Veliky Novgorod, 2014, 199 p.

[8] I.L. Litvinenko, N.N. Soloviev, I.A. Smirnova, "The Role of Agritourism Clusters in the Implementation of the Concept of Sustainable Development of the Region", Dilemmas contemporaneoseducacion politica y valores, vol. 6, iss. 3, Art. 71.

[9] A.R. Khanal, U. Honeyb, O. Omobitanb, "Diversification through 'fun in the farm': analyzing structural factors affecting agritourism in Tennessee", Int. Food and Agribusin. Manag. Rev., vol. 23, iss. 1, pp. $105-120,2020$

[10] R. Ciolac, T. Adamov, T. Iancu, G. Popescu, R. Lile, C. Rujescu, D. Marin, "Agritourism-A Sustainable Development Factor for Improving the 'Health' of Rural Settlements. Case Study Apuseni Mountains Area", Sustainability, vol. 11, no. 5, p. 1467, 2019.

[11] K. Fields, A. Hjalager, G. Richards, Demand for the gastronomy tourism product: Motivational factors. In Tourism and Gastronomy. London, UK: Routledge, 2002, pp. 37-50.

[12] R. Testa, A. Galati, G. Schifani, A. Maria Di Trapani, G. Migliore, "Culinary Tourism Experiences in Agri-Tourism Destinations and Sustainable Consumption-Understanding Italian Tourists' Motivations", Sustainability, vol. 11, no. 17, p. 4588, 2019.

[13] E.L. Dracheva, T.T. Hristov, "Gastronomic tourism: current trends and prospects", Russ. Reg.: a look into the future, no. 3, 2015.

[14] K.N. Laricheva, L.A. Kirkorov, Organization of Cultural Hunting. LAP LAMBERT Academic Publishing is an imprint of SIA OmniScriptum Publishing, 2018. $185 \mathrm{p}$.

[15] F. Bagi, R. Reeder, "Factors affecting farmer participation in agritourism", Agricult. and Resource Econ. Rev., vol. 41, no. 2, pp. 189-199, 2012.

[16] R.M. Torres, J.H. Momsen, Tourism and agriculture: new geographies of consumption, production and rural restructuring. London, UK: Routledge, $224 \mathrm{p}$.

[17] M.M. Voytyuk, Organization of rural tourism: Practical recommendations on the organization of alternative employment of the rural population. Moscow: Rosinformagroteh, 2010, 120 p. Retrieved from: http://www.iprbookshop.ru/15758.html. 